\title{
Enzymatic release of folate activity from the red cells in megaloblastic anaemia of pregnancy
}

\author{
HELENA GRZESIUKOWICZ, R. F. JENNISON, AND A. H. GOWENLOCK \\ From the Department of Clinical Pathology, St. Mary's Hospitals, Manchester, and the \\ Department of Chemical Pathology, University of Manchester
}

SYNOPSIS The content of folate activity precursors in washed red cells and the enzymatic plasma factor activity, necessary for the release of folate from the precursors, were studied in normal subjects and in patients with megaloblastic anaemia of pregnancy. Subjects with megaloblastic anaemia of pregnancy had a significantly reduced folate activity precursor content, and 14 subjects $(58 \%)$ had significantly low plasma factor activity, which in at least four subjects may have been due to the presence of inhibitors. This study indicates that impaired activity of the plasma factor may play a part in the aetiology of megaloblastic anaemia of pregnancy.

In recent years the method using Lactobacillus casei for determining serum folate activity has been widely used for assessing folic acid status in various conditions in man (Baker, Herbert, Frank, Pasher, Hutner, Wasserman, and Sobotka, 1959; Herbert, Baker, Frank, Pasher, Sobotka, and Wasserman, 1960; Waters and Mollin, 1961 ; Cooper and Lowenstein, 1961; Ball and Giles, 1964). Izak, Rachmilewitz, Sadovsky, Bercovici, Aronovitch, and Grossowicz (1961) and Grossowicz, Mandelbaum-Shavit, Davidoff, and Aronovitch (1962), measuring folate in both whole blood and serum, reported that serum contains only about $10 \%$ of the whole blood activity and that the bulk of the folate is located in the red cells.

Previously, Toennies, Usdin, and Phillips (1956) and Toennies and Phillips (1959) showed that the red cells contain large amounts of folate activity precursors, and that plasma and serum contain equal amounts of enzymatic factors (plasma factors) capable of releasing folate activity from folate activity precursors.

Since megaloblastic anaemia of pregnancy is characterized by low levels of folic acid in serum (Herbert et al., 1960; Waters and Mollin, 1961; Ball and Giles, 1964) and in whole blood (Izak et al., 1961; Grossowicz et al., 1962), it was felt advisable to investigate a possible deficiency of either plasma factor or folate activity precursors in these subjects compared with normal controls. Accordingly, plasma factor was measured in serum and folate activity precursor in erythrocytes.

Received for publication 1 April 1965.

\section{MATERIALS AND METHODS}

We studied 22 healthy control subjects, men and women who were not pregnant at the time; 25 pregnant women with low haemoglobin concentrations (less than 10g./ $100 \mathrm{ml}$.) and megaloblasts visible in marrow preparations; eight pregnant women with low haemoglobin concentration (less than $10 \mathrm{~g} . / 100 \mathrm{ml}$.) and a normoblastic marrow picture; and 24 normal pregnant subjects with a haemoglobin level above $12 \mathrm{~g} . / 100 \mathrm{ml}$.

Venous blood $(20 \mathrm{ml}$.) was collected from the subjects, preferably in a fasting state or at least two hours after a light meal. After clotting, serum was separated and stored at $-20^{\circ} \mathrm{C}$. without the addition of ascorbic acid. It was usually tested within two weeks.

The remaining blood clot was gently shaken with $6 \mathrm{ml}$. acid citrate dextrose, and the suspended erythrocytes were decanted and centrifuged at $1,400 \mathrm{~g}$ for $20 \mathrm{~min}$. in graduated tubes. The supernatant was removed and the packed cells were resuspended in 3 volumes of acid citrate dextrose. The suspension was either used immediately or stored at $4^{\circ} \mathrm{C}$. for not more than one week.

STANDARDS A standard preparation of folate activity precursors was made according to the method of Toennies et al. (1956). The partially purified powder was stored in a desiccator at room temperature. Fresh batches were prepared as required and compared with the existing batch before use.

For the standard plasma factor, serum obtained at intervals from the same normal subject was used. The enzymatic activity of this serum was frequently checked with a standard preparation of folate activity precursor and remained apparently constant.

ASSAY FOR FOLATE ACTIVITY Folate activity was determined with $L$. case $i$ using a modification of the methods 
of Waters and Mollin (1961) and Herbert (1961). Dehydrated Difco $L$. casei medium was used. The buffers employed were $0.1 \mathrm{M}$ phosphate buffer of $p \mathrm{H} 6 \cdot 1$, containing $200 \mathrm{mg} . \%$ ascorbic acid $(0.1 \mathrm{M}$ phosphate ascorbate buffer), and $0.05 \mathrm{M}$ phosphate buffer of $p \mathrm{H}$ $6 \cdot 1$, containing $100 \mathrm{mg} . \%$ ascorbic acid (0.05 M phosphate ascorbate buffer). Serum was diluted 1 in 20 with $0 \cdot 1 \mathrm{M}$ phosphate ascorbate buffer before assay.

FOLATE ACTIVITY PRECURSOR CONTENT OF THE RED CELLS The content of fclate activity precursors was expressed as the amount of folate activity released from the preparation of washed red cells by an amount of standard plasma factor known to release all the folate activity from the amount of folate activity precursor likely to be present under the standard conditions.

The erythrocyte suspension was recentrifuged for $20 \mathrm{~min}$. at 1,400 $\mathrm{g}$ and a fresh suspension (1 in 4) in acid citrate dextrose was made. It was haemolysed by diluting it 1 in 10 with $0.05 \mathrm{M}$ phosphate ascorbate buffer, and then recentrifuged. To $0.8 \mathrm{ml}$. of the clear red haemolysate (corresponding to $0.02 \mathrm{ml}$. of the red cells), $19.0 \mathrm{ml}$. of $0.05 \mathrm{M}$ phosphate ascorbate buffer was added, followed by $0.2 \mathrm{ml}$. of the standard plasma factor preparation. A plasma factor blank was prepared by adding $2.2 \mathrm{ml}$. of standard plasma to $19.8 \mathrm{ml}$. of $0.05 \mathrm{M}$ phosphate ascorbate buffer, and a folate activity precursor blank by adding $0.8 \mathrm{ml}$. of red cell haemolysate to $19.0 \mathrm{ml}$. of $0.05 \mathrm{M}$ phosphate ascorbate buffer and $0.2 \mathrm{ml}$. of water. The three samples were incubated at $37^{\circ} \mathrm{C}$. for $90 \mathrm{~min}$. before assay.

The folate activity precursor content of the red cells was calculated by subtracting the folate activity of the two blanks from the test and multiplying by 50 , and was expressed in $\mathrm{ng} . / \mathrm{ml}$. of erythrocytes.

PLASMA FACTOR ACTIVITY OF SERUM Plasma factor activity was expressed as the amount of folate activity released by $0.2 \mathrm{ml}$. of serum under test from an amount of a standard preparation of folate activity precursor known to saturate at least $0.5 \mathrm{ml}$. of the standard serum.

The serum under test $(0.2 \mathrm{ml}$.) was added to $3 \mathrm{mg}$. standard folate activity precursor in $19.8 \mathrm{ml}$. of $0.05 \mathrm{M}$ phosphate ascorbate buffer. Serum and folate activity precursor blanks were also prepared. The three samples were incubated at $37^{\circ} \mathrm{C}$. for $90 \mathrm{~min}$. before assay.

The plasma factor activity was calculated by subtracting folate activity levels of the two blanks from the test and multiplying by 5 , and was expressed in $\mathrm{ng} . / \mathrm{ml}$. serum.

In experiments discussed later, $6 \mathrm{mg}$. of the standard folate activity precursor was used with 0.2 to $1.0 \mathrm{ml}$. of the test serum, made up to a final volume of $20 \mathrm{ml}$. with
$0.05 \mathrm{M}$ phosphate ascorbate buffer. Further incubation and assay was as before.

EFFECT OF SERUM DIALYSATES ON STANDARD FOLATE ACTIVITY RELEASE FROM FOLATE ACTIVITY PRECURSORS $\bar{\omega}$ Sera $(5 \mathrm{ml}$.) from different subjects were dialysed $\vec{\nabla}$ overnight at room temperature, using Visking tubing, against $50 \mathrm{ml}$. of distilled water. Samples, each of $9.5 \mathrm{ml}$. ڤొ of the dialysates, were included in the incubation mixture $\vec{\circ}$ for standard folate activity release from folate activity precursor. The composition of the final mixture was $\overrightarrow{\vec{\omega}}$ otherwise unchanged. Incubation and final assay were as usual. The activity corrected for blanks was expressed as $\bar{\Omega}$ the percentage difference from the activity in the absence of dialysate.

\section{RESULTS}

FOLATE ACTIVITY PRECURSOR CONTENT OF THE RED CELLS Table I shows the serum folate activity and the folate activity precursor content of the red cells in control subjects, in women with megaloblastic anaemia of pregnancy, and in subjects with normoblastic anaemia of pregnancy.

The content of folate activity precursor in $\vec{\oplus}$ erythrocytes is significantly lower in megaloblastic of anaemia of pregnancy compared with the controls $(P<0.001)$ or pregnant women with normoblastic anaemia $(P=0.001)$. The latter two groups differ significantly $(P=0.02)$. Only three subjects with megaloblastic anaemia of pregnancy had values greater than $325 \mathrm{ng} . / \mathrm{ml}$., which was the lowest value in control subjects.

PLASMA FACTOR ACTIVITY OF SERUM Plasma factor was determined in the three conditions previously investigated. A second control group of normal pregnant women has now been included. Individual results appear in Fig. 1 and grouped results in Table II.

Subjects with megaloblastic anaemia of pregnancy have significantly lower plasma factor activity than control or normal pregnant subjects $(P<0.001)$ or pregnant women with normoblastic anaemia $(\mathbf{P}=$ $0 \cdot 001$ ). Normal pregnant women have significantly higher plasma factor activity than control subjects $(\mathrm{P}<\mathbf{0 . 0 0 1 )}$ or women with normoblastic anaemia $(P=0.001)$. In the control group there is no

TABLE I

SERUM FOLATE AND FOLATE ACTIVITY PRECURSOR OF THE RED CELLS

\begin{tabular}{|c|c|c|c|c|c|c|c|}
\hline \multirow[t]{2}{*}{ Condition } & \multirow[t]{2}{*}{$\begin{array}{l}\text { No. of } \\
\text { Cases }\end{array}$} & \multicolumn{3}{|c|}{ Serum Folate $(\mathrm{ng} . / \mathrm{ml}$.) } & \multicolumn{3}{|c|}{$\begin{array}{l}\text { Folate Activity Precursor Content } \\
\text { (ng./ml.) }\end{array}$} \\
\hline & & Range & Mean & S.D. & Range & Mean & S.D. \\
\hline $\begin{array}{l}\text { Control } \\
\text { Megaloblastic anaemia of pregnancy } \\
\text { Normoblastic anaemia of pregnancy }\end{array}$ & $\begin{array}{r}22 \\
18 \\
8\end{array}$ & $\begin{array}{l}6 \cdot 7-14 \cdot 6 \\
0 \cdot 7-3 \cdot 8 \\
4 \cdot 8-10 \cdot 0\end{array}$ & $\begin{array}{l}9 \cdot 20 \\
2 \cdot 03 \\
6 \cdot 35\end{array}$ & $\begin{array}{l}2 \cdot 00 \\
0 \cdot 96 \\
1 \cdot 77\end{array}$ & $\begin{array}{r}325-470 \\
90-395 \\
315-425\end{array}$ & $\begin{array}{l}407 \cdot 3 \\
240 \cdot 0 \\
370 \cdot 0\end{array}$ & $\begin{array}{l}35 \cdot 1 \\
89 \cdot 4 \\
36 \cdot 7\end{array}$ \\
\hline
\end{tabular}

$1 \cdot 77$

315-425

$240 \cdot 0$
$370 \cdot 0$

$36 \cdot 7$ 


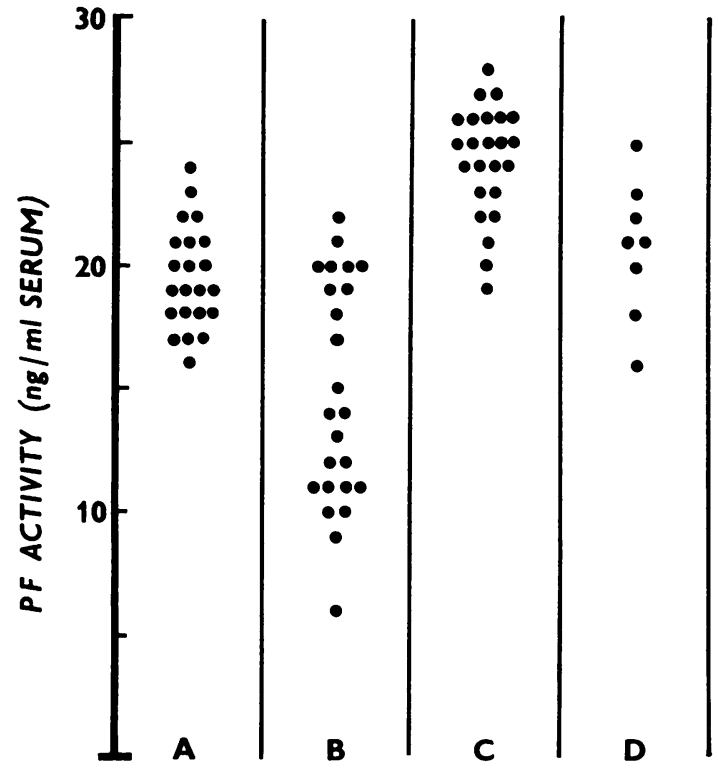

FIG. 1. Plasma factor (PF) activity of sera from nonpregnant controls $(A)$, subjects with megaloblastic anaemia of pregnancy $(B)$, normal pregnant controls $(C)$, and subjects with normoblastic anaemia of pregnancy $(D)$.

difference in plasma factor between male (8) and female (14) subjects $(P<0 \cdot 1)$. Women with normoblastic anaemia do not differ from control subjects $(\mathbf{P}>\mathbf{0} \cdot \mathbf{1})$.

It can be seen in Fig. 1 that subjects with megaloblastic anaemia do not form a homogenous group. They can be further divided into 10 subjects with plasma factor activity (range 17.0-21.5 ng./ml.; mean $19 \cdot 4$; S.D. 1.35) not significantly different from controls or patients with normoblastic anaemia of pregnancy but significantly lower $(P<0.001)$ than normal pregnant women, and 14 subjects with plasma factor activity (range $6 \cdot 0-15 \cdot 0 \mathrm{ng} . / \mathrm{ml}$.; mean $11 \cdot 1$; S.D. 2.29) significantly lower $(P<0.001)$ than all other groups.

CORRELATION BETWEEN SERUM FOLATE ACTIVITY, PLASMA FACTOR, AND FOLATE ACTIVITY PRECURSOR In 22 control subjects not pregnant, significant correlation was found between serum folate activity and folate activity precursor $(r=0.50 ; 0.02>P>$
$0.01)$ and plasma factor and folate activity precursor $(\mathrm{r}=0.46 ; 0.05>\mathrm{P}>0.02)$ but no correlation between serum folate activity and plasma factor $(\mathrm{r}=0.09 ; \mathrm{P}>0.1)$.

In 24 normal pregnant subjects no significant correlation was found between serum folate activity and plasma factor $(r=0.36 ; P>0.05)$. No figures were available for folate activity precursor to calculate the correlation between folate activity and its precursor.

In eight pregnant subjects with normoblastic anaemia no significant correlation was established between folate activity and its precursor $(r=0.07$; $P>0.1)$, or between folate activity and plasma factor $(r=0.15 ; P>0.1)$. There are, however, fewer subjects in this group.

In 17 subjects with megaloblastic anaemia of pregnancy there was a very significant correlation between serum folate activity and plasma factor $(r=0.85 ; P<0.001)$, and a less significant one between folate activity and its precursor $(r=0.51$; $0.05>P>0.02)$. There was no correlation between plasma factor and folate activity precursor $(r=0 \cdot 13$; $P>0.01$ ).

In non-pregnant subjects serum folate activity depends on the amount of its precursor. In megaloblastic anaemia of pregnancy serum folate activity seems to depend both on its precursor and on plasma factor. Thus low values for plasma factor found in 14 subjects $(58 \%)$ with megaloblastic anaemia of pregnancy may be partially responsible for low serum folate activity and cumulatively for megaloblastic erythropoiesis.

EFFECT OF INCREASING SERUM PLASMA FACTOR ON FOLATE ACTIVITY RELEASE FROM FOLATE ACTIVITY PRECURSORS Figure 2 shows the effect of increasing the concentration of plasma factor in the incubation mixture on folate activity release from a constant amount of folate activity precursors.

Curve $A$ represents the mean response for five normal subjects. Curves B, C, D, and E are examples of the effect obtained with sera from subjects with megaloblastic anaemia of pregnancy. In all four curves the amount of folate activity release is less than the normal.

Although curves $B$ and $E$ suggest deficiency of enzymes, curves $\mathrm{C}$ and $\mathrm{D}$ are more difficult to

TABLE II

SERUM FOLATE AND PLASMA FACTOR ACTIVITY

\begin{tabular}{|c|c|c|c|c|c|c|c|}
\hline \multirow[t]{2}{*}{ Condition } & \multirow{2}{*}{$\begin{array}{l}\text { No. of } \\
\text { Cases }\end{array}$} & \multicolumn{3}{|c|}{ Serum Folate $(\mathrm{ng} . / \mathrm{ml})}$. & \multicolumn{3}{|c|}{ Plasma Factor Activity (ng. $/ \mathrm{ml}$.) } \\
\hline & & Range & Mean & S.D. & Range & Mean & S.D. \\
\hline $\begin{array}{l}\text { Control } \\
\text { Megaloblastic anaemia of pregnancy } \\
\text { Normal pregnant } \\
\text { Normoblastic anaemia of pregnancy }\end{array}$ & $\begin{array}{r}22 \\
24 \\
24 \\
8\end{array}$ & $\begin{array}{l}6 \cdot 7-14 \cdot 6 \\
0 \cdot 6-3 \cdot 8 \\
5 \cdot 2-11 \cdot 1 \\
4 \cdot 8-10 \cdot 0\end{array}$ & $\begin{array}{l}9 \cdot 20 \\
2 \cdot 01 \\
6 \cdot 70 \\
6 \cdot 35\end{array}$ & $\begin{array}{l}2 \cdot 00 \\
0 \cdot 96 \\
1 \cdot 36 \\
1 \cdot 77\end{array}$ & $\begin{array}{r}16 \cdot 0-23 \cdot 5 \\
6 \cdot 0-21 \cdot 5 \\
19 \cdot 0-28 \cdot 0 \\
16 \cdot 0-25 \cdot 0\end{array}$ & $\begin{array}{l}19 \cdot 3 \\
14 \cdot 6 \\
24 \cdot 0 \\
20 \cdot 5\end{array}$ & $\begin{array}{l}1 \cdot 84 \\
4 \cdot 58 \\
2 \cdot 18 \\
2 \cdot 80\end{array}$ \\
\hline
\end{tabular}




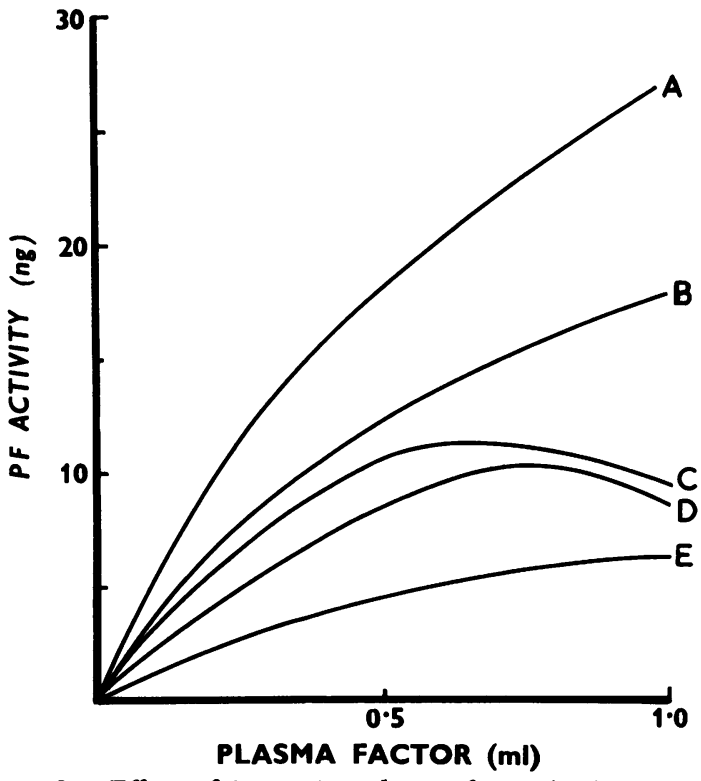

FIG. 2. Effect of increasing plasma factor (PF) activity on the release of folate activity from precursors. For details see text.

interpret. The shape may result from the presence of enzyme inhibitors in the serum, but as the system is so complex, and the number of factors in plasma factor uncertain, further speculation is unprofitable.

Altogether sera from nine subjects with megaloblastic anaemia of pregnancy were tested. Five showed responses similar to curves $B$ and $E$, and four were like curves $\mathbf{C}$ and $\mathbf{D}$.

EFFECT OF SERUM DIALYSATES ON STANDARD FOLATE ACTIVITY RELEASE FROM PRECURSORS Dialysates from the sera of three control subjects had a negligible effect on the standard reaction. The percentage differences were $-1 \cdot 1,+1 \cdot 2$, and $+7 \cdot 0$.

Serum dialysates from seven subjects with megaloblastic anaemia of pregnancy gave a wider range of percentage differences, viz., $-22 \cdot 1,-16 \cdot 2$, $-13 \cdot 3,-11 \cdot 1,-2 \cdot 4,+2 \cdot 2$, and $+8 \cdot 2$.

Thus in four subjects with megaloblastic anaemia of pregnancy, serum dialysates depressed the standard reaction by more than $10 \%$, suggesting the presence of inhibitors.

\section{DISCUSSION}

Toennies et al. (1956), Toennies and Phillips (1959), and Noronha and Aboobaker (1963) showed that the bulk of folate activity resides in the red cells as folate activity precursors. The former workers have further indicated that human plasma contains a factor capable of releasing folate activity from its precursors. Thus serum folate activity, shown by Herbert, Larrabee, and Buchanan (1962) to be mainly 5-methyl-tetrahydrofolic acid (5- $\mathrm{CH}_{3}$-THFA), may be derived from the action of plasma factor on folate activity precursors released by the red cells when they undergo destruction at the end of their life span. In addition serum may contain folate factors directly derived from the diet.

That both dietary folic acid and folate derived from the red cells play a part in folate metabolism in man is suggested by the results of Herbert (1962). In this study, a healthy physician developed folate deficiency megaloblastic anaemia after four and a half months on a diet deficient in folic acid; at that time his erythrocyte 'folate' stores were exhausted.

A possible scheme for folic acid turnover in blood, shown in Fig. 3, indicates that folate deficiency in anaemic subjects may be due to dietary lack of folic acid, abnormal release of folate activity from its precursors in the erythrocyte, or disturbed conversion and utilization of folate compounds.

The red cell appears to be the main storage site for folate activity precursors in blood. In anaemic subjects the red cell mass, and thus folate activity precursor, is reduced. The anaemia may be caused in the first instance by any erythropoietic disturbance or by haemorrhage as well as by folic acid depletion alone. If the anaemia is not corrected or supplemented with folic acid, the diminishing circulating red cell mass will release less folate, further depressing red cell formation. The cumulative effect may lead to depletion of folate stores and eventually to a megaloblastic marrow.

In subjects with megaloblastic anaemia of pregnancy, low folate levels are well recognized but the cause of this reduction is problematic. Since there is significant correlation between serum folate activity and its precursor in the erythrocyte, both in control subjects and in women with megaloblastic anaemia of pregnancy, low serum folate activity values may indicate a decreased total folate activity precursor content due to reduced red cell volume or to diminished deposits of precursor within the red cells. The reduced concentration of precursor found in the erythrocytes of subjects with megaloblastic anaemia of pregnancy (Table I) suggests that folate deprivation has existed for some time. Folate enters only young erythrocytes (Herbert and Zalusky, 1962) and it takes about 120 days for a normal red cell to be completely replaced by a folate-deficient cell (Herbert, 1964).

The initial cause of folate depletion in pregnant subjects is uncertain. Dietary deficiency, excessive demands of the foetus, and impaired absorption of folate have been implicated. The foetus obtains all 


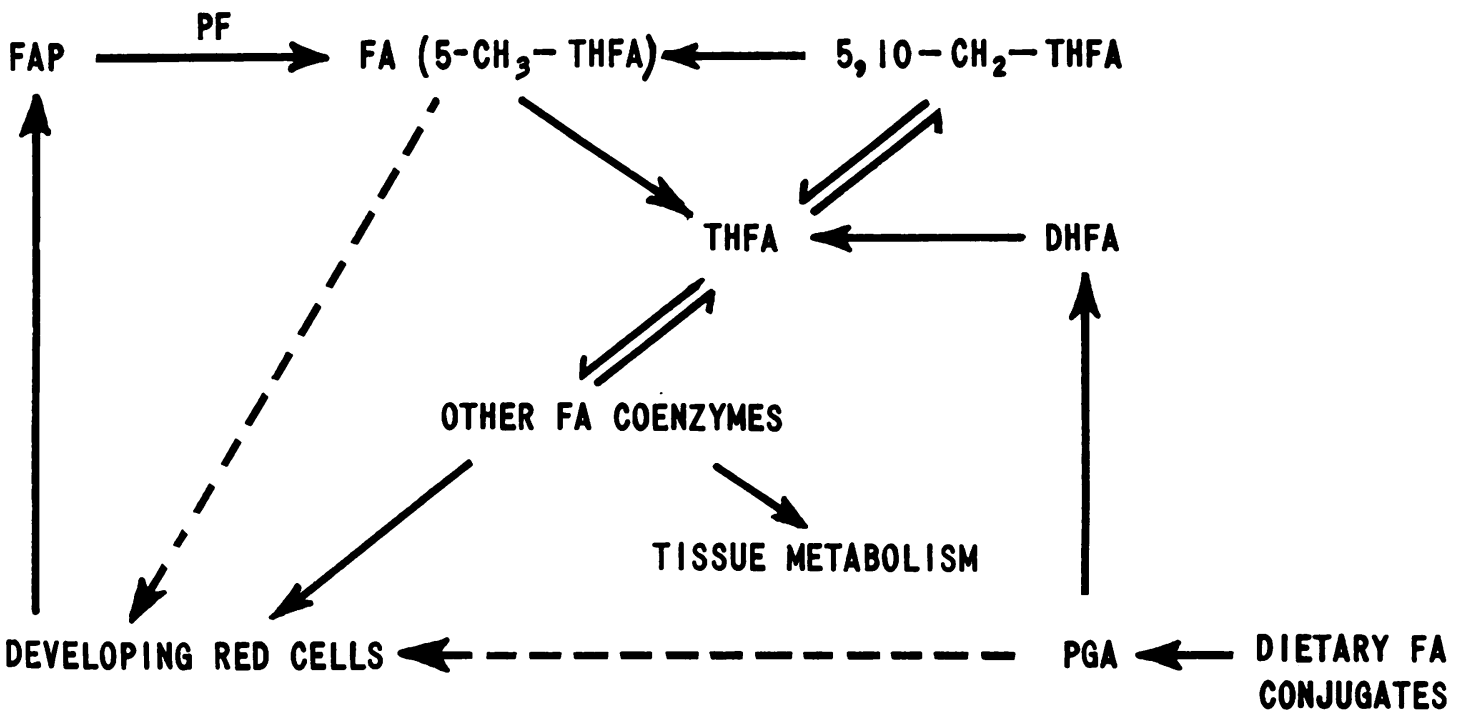

FIG. 3. Simplified scheme for folic acid turnover in blood.

its folate from the mother and its demands may precipitate megaloblastic anaemia if the mother already suffers from folate deficiency, either from malnutrition or malabsorption. In the cases of Izak et al. (1961), foetal demand seemed an important factor. In apparently normal pregnant subjects, lower serum folate (Ball and Giles, 1964), and more rapid clearance of folic acid from the serum (Chanarin, Anderson, and Mollin, 1958a; Chanarin, Mollin, and Anderson, 1958b; Chanarin, MacGibbon, O'Sullivan, and Mollin, 1959) suggest that in pregnancy turnover of folate is increased. Low vitamin $B_{12}$ levels found in some subjects with megaloblastic anaemia of pregnancy (Baker et al., 1959; Cox, Matthews, Meynell, Cooke, and Gaddie, 1960; Izak, et al., 1961; Ball and Giles, 1964) may also contribute to folate depletion, since vitamin $B_{12}$ is involved in folate conversion and utilization (Herbert and Zalusky, 1962; Larrabee, Rosenthal, Cathou, and Buchanan, 1963; Waters and Mollin, 1963; Cooper and Lowenstein, 1964).

Our experiments with plasma factor activity indicate that yet another factor may be responsible for folate deficiency in megaloblastic anaemia of pregnancy. Although no correlation could be established between serum folate activity and plasma factor in non-pregnant or normal pregnant controls, in subjects with megaloblastic anaemia of pregnancy the correlation is highly significant.

Of 24 subjects with megaloblastic anaemia of pregnancy, 14 had significantly reduced plasma factor activity compared with non-pregnant subjects, and all had diminished activity compared with normal pregnant controls. Subjects with depressed plasma folate activity may be less able to utilize folate activity precursor released from the red cells, thus reducing the amount of the 'available' folate in circulation.

It is difficult to establish if a low level of plasma factor in subjects with megaloblastic anaemia of pregnancy is due to the diminished production of enzymes, deficiency of enzyme activators, or the presence of inhibitors. The possibility exists that plasma factor may be produced according to demand, and a low level may merely reflect a diminished content of folate activity precursor. Thus in normal pregnancy plasma factor may rise to cope with an increased total folate activity precursor, due to the increment in total red cell mass.

However, curves $C$ and $D$ in Fig. 1, and the depressive effect of serum dialysates from four out of seven subjects studied, suggest that in some subjects with megaloblastic anaemia of pregnancy low plasma factor activity may be due to the presence of inhibitors.

One of us (H.G.) is indebted to the Research Grants Committee of the United Manchester Hospitals for financial support.

\section{REFERENCES}

Baker, H., Herbert, V., Frank, O., Pasher, I., Hutner, S. H., Wasserman, L. R., and Sobotka, H. (1959). Clin. Chem., 5, 275.

Ball, E. W., and Giles, C. (1964). J. clin. Path., 17, 165.

Chanarin, I., Anderson, B. B., and Mollin, D. L. (1958a). Brit. J. Haemat., 4, 156. 
Chanarin, MacGibbon, B. M., O'Sullivan, W. J., and Mollin, D. L. (1959). Lancet, 2, 634.

Cooper, B. A., and Lowenstein, L. (1961). Canad. med. Ass. J., 85, 987.

- - (1964). Blood, 24, 502

Cox, E. V., Matthews, D. M., Meynell, M. J., Cooke, W. T., and Gaddie, R. (1960). Ibid., 15, 376.

Grossowicz, N., Mandelbaum-Shavit, F., Davidoff, R., and Aronovitch, J. (1962). Ibid., 20, 609.

Herbert, V. (1961). J. clin. Invest., 40, 81.

(1962). Trans. Ass. Amer. Phycns, 75, 307.

(1964). Proc. roy. Soc. Med., 57, 377.

_-, Baker, H., Frank, O., Pasher, I., Sobotka, Q., and Wasserman, L. R. (1960). Blood, 15, 228.
—, Larrabee, A. R., and Buchanan, J. M. (1962). J. clin. Invest., 41, 1134.

and Zalusky, R. (1962). Ibid., 41, 1263.

Izak, G., Rachmilewitz, N., Sadovsky, A., Bercovici, B., Aronovitch, J., and Grossowicz, N. (1961). Amer. J. clin. Nutr., 9, 473.

Larrabee, A. R., Rosenthal, S., Cathou, R. E., and Buchanan, J. M. (1963). J. biol. Chem., 238, 1025.

Noronha, J. M., and Aboobaker, V. S. (1963). Arch. Biochem., 101, 445.

Toennies, C., Usdin, E., and Phillips, P. M. (1956). J. biol. Chem., 221, 855

_- and Phillips, P. N. (1959). Ibid., 234, 2369.

Waters, A. H., and Mollin, D. L. (1961). J. clin. Path., 14, 335.

,- (1963). Brit. J. Haemat., 9, 319. 